THE JOURNAL GASTRONOMY TOURISM

Volume 4 Nomor 1, Juni 2017, 27-36

Tersedia daring di:

https://ejournal.upi.edu/index.php/gastur

Gastronomy Tourism Journal

\title{
Strategi Peningkatan Penjualan Di Suis Butcher Cabang Setiabudi
}

\author{
Neli Anggraeni ${ }^{1}$, Dewi Turgarini ${ }^{1}$, Reiza Miftah ${ }^{2}$ \\ ${ }^{1}$ Manajemen Industri Katering, Fakultas Pendidikan Ilmu Pengetahuan Sosial, Universitas \\ Pendidikan Indonesia, Jl. Dr. Setiabudhi No. 229, Bandung 40154, Indonesia \\ ${ }^{2}$ Manajemen Resort and Leisure, Fakultas Pendidikan Ilmu Pengetahuan Sosial, Universitas \\ Pendidikan Indonesia, Jl. Dr. Setiabudhi No. 229, Bandung 40154, Indonesia \\ * Koresponding Penulis. E-mail: nelianggraeni@ student.upi.edu (Neli Anggraeni)
}

\begin{abstract}
Abstrak
Suis Butcher adalah salah satu steak house yang berada di kota Bandung yang telah berdiri sejak tahun 1984. Suis Butcher mengalami penurunan omzet penjualan, hal tersebut membuat petingnya perumusan strategi yang tepat bagi. Tujuan dilakukan penelitian ini adalah: (1) mengetahui bagaimana proses manajemen strategi di Suis Butcher (2) mengetahui faktor-faktor strategi eksternal yang merupakan peluang dan ancaman di Suis Butcher, (3) mengetahui faktor-faktor strategi internal yang merupakan kekuatan dan kelemahan di Suis Butcher, (3) mengetahui strategi peningkatan penjualan yang dapat diterapkan oleh Suis Butcher berdasarkan analisis SWOT. Metodologi yang digunakan adalah analisis deskriptif kualitatif dan kuantitatif dengan menggunakan wawancara mendalam dan kuesioner untuk mengetahui gambaran mengenai lingkungan perusahaan yang terdiri atas kekuatan, kelemahan, peluang dan ancaman. Data yang diperoleh kemudian dianalisis menggunakan matriks IFAS, matriks EFAS, matriks IE, diagram kartesius, matriks SWOT dam QSPM. Hasil analisis menunjukan terdapat sembilan alternatif strataegi yang dapat diterapkan Suis Butcher dengan strategi utama yaitu Memanfaatkan perkembangan teknologi untuk meningkatkan promosi dengan total skor 5,97 .
\end{abstract}

Kata Kunci: Manajemen Strategi; Analisis SWOT; Quantitative Strategy Planning Matrix; Steak House.

\section{Pendahuluan}

Kuliner merupakan kata serapan dari Menurut Undang Undang Republik Indonesia No 10 Tahun 2009 Pasal 1 Pariwisata adalah berbagai macam kegiatan wisata dan didukung berbagai fasilitas serta layanan yang disediakan oleh masyarakat, pengusaha, pemerintah, dan pemerintah daerah. Pariwisata berpeluang menjadi andalan penghasil devisa Indonesia, untuk itu langkah pemerintah untuk menekan sektor pariwisata dinilai sebagai strategi yang tepat karena apabila sektor pariwisata berkembang maka akan memacu berkembanganya sektor industri lain seperti industri kerajinan tangan, perhotelan, kuliner serta industri lainnya yang berhubungan dengan pariwisata.

Berdasarkan pengertian tersebut maka dibutuhkan fasilitas dan pelayanan yang dapat menunjang kegiatan wisatawan seperti perhotelan, restoran, akomodasi serta fasilitas penunjuang lainnya yang dapat memuaskan kebutuhan para wisatawan.

Restoran merupakan fasilitas penunjang yang menyediakan makanan dan minuman bagi para wisatawan. Baik itu makanan dan minuman lokal wilayah itu sendiri maupun makanan atau minuman dari negara lain. Salah satu fasilitas ini merupakan hal yang penting dalam sektor pariwisata karenanya fasilitas tersebut harus dikelola dan dikembangkan dengan baik. 
Menurut Undang Undang Republik Indonesia No 10 pasal 1 ayat 10 Tahun 2009 tentang Kepariwisataan Kawasan strategis pariwisata adalah kawasan yang memiliki fungsi utama pariwisata atau memiliki potensi untuk pengembangan pariwisata yang mempunyai pengaruh penting dalam satu atau lebih aspek, seperti pertumbuhan ekonomi, sosial dan budaya, daya dukung lingkungan hidup, serta pertahanan dan keamanan.

United Nations of Educational, Scientific, and Cultural Organization (UNESCO) menetapkan Bandung sebagai kota wisata, penetapan tersebut ditelaksanakan di Beijing, China pada 25 September 2013. (Laporan Kinerja Instansi Pemerintas Dinas Kebudayaan dan Pariwisata Kota Bandung Tahun 2015, 2015) Bandung bersama empat kota atau daerah lainnya yakni Yogyakarta, Solo, Semarang, dan Bali, ditetapkan sebagai destinasi wisata kuliner Indonesia oleh Kementerian Pariwisata. (Widianto, 2015) Seperti diketahui bahwa Bandung merupakan salah satu kota kuliner yang mana hampir disetiap sudut kota terdapat berbagai macam kuliner yang dijajakan mulai dari restoran, rumah makan sampai dengan street food.

Salah satu dari banyaknya restoran yang berada di kota Bandung adalah Suis Butcher (SB). Suis Butcher adalah sebuah restoran steak yang telah berdiri sejak tahun 1984 Suis Butcher sebagai salah satu restoran steak, namun tidak hanya menyajikan makanan dan minuman, pengunjungpun akan disuguhkan dengan suasana restoran bernuansa vintage dan lukisan-lukisan yang menempel didinding restoran, upaya tersebut dilakuakan pihak pengelola untuk memberikan kenyamanan bagi pengunjung sehingga dapat memuaskan keinginan pengunjung, namun upaya tersebut tidak sejalan dengan volume penjualan yang naik turun.
Tujuan dilakukannya penelitian ini adalah sebagai berikut:
a. Mengetahui dan menganalisis bagaimana proses manajemen strategi Suis Butcher.
b. Mengetahui dan menganalisis masalah eksternal yang dihadapi Suis Butcher.
c. Mengetahui dan menganalisis masalah internal yang dihadapi Suis Butcher.
d. Untuk mengetahui strategi apa yang perlu dilakukan oleh Suis Butcher.

\subsection{Pariwisata}

Istilah pariwisata berasal dari bahasa Sansekerta yang komponen-komponennya terdiri dari: pari yang berarti penuh, lengkap, berkeliling. Wis (man) yang berarti rumah, properti, kampung komunitas. Dan atau yang berarti pergi terus menerus, mengembara yang bila dirangkai menjadi satu kata menjadi istilah Pariwisata, berarti pergi secara lengkap meninggalkan rumah (kampung) berkeliling terus-menerus. Kenyataannya istilah pariwisata sebagai pengganti istilah asing "tourism" atau "travel" diberi makna oleh Pemerintah Indonesia "Mereka yang meninggalkan rumah untuk mrengadakan perjalanan tanpa mencari nafkah ditempat-tempat yang dikunjungi sambil menikmati kunjungan mereka" (S.Pendit, 2003, p. 1).

\subsection{Restoran}

Restoran adalah suatu tempat yang diorganisasi secara komersial, yang menyelenggarakan pelayanan dengan baik terhadap semua tamunya berupa makanan atau minuman. (Marsum, 2005, p. 7).

.Specialty Restaurant adalah restoran yang suasana dan dekorasi seluruhnya disesuaikan dengan tipe khas makanan yang disajikan atau temanya. Restoran-restoran semacam ini menyediakan masakan Cina, Jepang, India, Italia dan sebagainya. Pelayanannya sedikit banyak berdasarkan 
tata cara Negara tempat asal makanan special itu. (Marsum, 2005, p. 11)

\subsection{Manajemen Strategi}

Manajemen strategi dapat didefinisikan sebagai seni dan pengetahuan dalam merumuskan, mengimplementasikan, serta mengevaluasi keputusan-keputusan lintas fungsional yang memampukan sebuah organisasi mencapai tujuannya (David, 2010, p. 5). Sebagaimana disiratkan oleh definisi ini, manajemen strategi berfokus pada usaha untuk mengintegrasikan manajemen,

keuangan/akuntansi, produksi/oprasi, penelitian dan pengembangan, serta sistem informasi komputer untuk mencapai keberhasilan organisasional. Tujuan manajemen strategi adalah untuk mengekploitasi serta menciptakan berbagai peluang baru dan berbeda untuk esok; perencanaan jangka panjang, sebaliknya, berusaha untuk mengoptimalkan tren-tren dewasa ini untuk esok.

\subsection{Proses Manajemen Strategi}

Menurut Wheelem dan Hunger (2001, p. 9) proses manajemen strategis meliputi empat elemen dasar yaitu sebagai berikut:

a. Pengamatan lingkungan

Pengamatan lingkungan adalah pemantauan, pengevaluasian, penyebaran informasi dari lingkungan eksternal kepada orang-orang yang berada dalam perusahaan. Pengamatan adalah alat manajemen untuk menghindari kegagalan strategis dan memastikan keadaan manajemen dalam jangka panjang.

b. Perumusan strategis

Perumusan strategi adalah pengembangan rencana jangka panjang untuk manajemen efektif dari kesempatan dan anacaman lingkungan dilihat dari kekuatan dan kelemahan perusahaan. Perumusan strategi meliputi menentukan misi perusahaan, menentukan tujuan-tujuan yang dapat dicapai, pengembangan strategi, dan penetapan pedoman kebijakan.

c. Implementasi strategis

Impplementasi startegis adalah proses dimana manajemen mewujudkan strategi dan kebijakan dalam tindakan melalui pengembangan program, anggaran, dan prosedur

d. Evaluasi dan pengendalian

Evaluasi dan pengendalian adalah proses yang melaluinya aktivitas-aktivitas perusahaan dan hasil kinerja di monitor dan kinerja yang sesungguhnya dibandingkan dengan kinerja yang diinginkan.

\subsection{Strategi Peningkatan Penjualan}

Strategi adalah suatu perencanaan induk komprehensif, yang menjelaskan bagaimana perusahaan akan mencapai semua tujuan yang telah ditetapkan oleh perusahaan berdasarkan misi yang telah ditentukan sebelumnya. (Rangkuti, 2016, hal. 239)

Peningkatan berarti kemajuan. Secara umum, peningkatan merupakan upaya untuk menambah derajat, tingkat, dan kualitas maupun kuantitas. Peningkatan juga dapat berarti penambahan keterampilan dan kemampuan agar menjadi lebih baik. Selain itu, peningkatan juga berarti pencapaian dalam proses, ukuran, sifat, hubungan dan sebagainya. (S, Adi, 2014)

Penjualan adalah suatu usaha yang terpadu untuk mengembangkan rencanarencana strategis yang diarahkan pada usaha pemuasan kebutuhan dan keinginan pembeli, guna mendapatkan penjualan yang menghasilkan laba (Marwan, 1991).

\section{Metode Penelitian}

Objek penelitian dalam penelitian ini adalah lingkungan internal dan eksternal dari Suis Butcher. Metode penelitian yang akan digunakan penulis dalam penelitian ini adalah metode deskriptif kualitatif dan kuantitatif. Populasi dalam penelitian ini 
adalah pengunjung dari Suis Butcher Cabang Setiabudi dan sampel yang digunakan sebanyak 100 orang. Instrumen yang digunakan yaitu kuesioner yang dibagikan kepada sampel.

\section{Hasil dan Pembahasan}

\subsection{Proses Manajemen Strategi di Suis Butcher}

\subsubsection{Pengamatan Lingkungan}

Suis Butcher melakukan pegamatan eksternal dengan cara:

a. Melihat tren yang sedang popular.

b. Memperhatikan apa yang konsumen inginkan.

c. Melihat keadaan pesaing

d. Promosi apa yang diterapkan oleh pesaing.

\subsubsection{Perumusan strategis}

Setelah dilakukan pengamatan terhadap lingkungan internal dan eksternal, selanjutnya Suis Butcher merumuskan strategi apa yang akan diterapkan selanjutnya. Perumusan strategi dilakukan oleh para petinggi-petinggi seperti owner, para manager baik itu personel manager, purchasing manager, accounting manager sampai dengan supervisior. Suis Butcher. kemudian setelah strategi ditetapkan maka akan diinformasikan terhadap semua karyawan. Namun, pada kenyataannya tidak banyak karyawan yang mengetahui strategi apa yang diterapkan oleh Suis Butcher. Berikut hasil survei terhadap 10 orang responden yaitu karyawan Suis Butcher

Tabel 1. Pengetahuan Strategi Karyawan Suis Butcher

\begin{tabular}{lccc}
\hline \multicolumn{1}{c}{$\begin{array}{c}\text { Tanggapan } \\
\text { Responden }\end{array}$} & Jumlah & Presentase (\%) & Skor \\
\hline 1(tidak tahu) & 1 & $10 \%$ & 1 \\
2(kurang tahu) & 6 & $60 \%$ & 12 \\
3 (tahu) & 2 & $20 \%$ & 6 \\
$4($ sangat tahu) & 1 & $10 \%$ & 4 \\
Total & 10 & $100 \%$ & 23 \\
\hline Sumber: Pengolahan data Februari $(2017)$ &
\end{tabular}

Tabel tersebut menunjukan dari 10 orang karyawan, 1 orang atau 10\% tidak mengetahui tentang strategi yang diterapkan oleh Suis Butcher. 6 orang atau $60 \%$ menjawab kurang tahu. 2 orang atau $20 \%$ menjawab tahu. 1 orang atau $10 \%$ menjawab sangat tahu. Berdasarkan tabel tersebut dapat dilihat bahwa kurangnya informasi yang disebarkan terhadap para karyawan. Jika karyawan mengetahui strategi apa yang diterapkan maka diharapkan karyawan dapat ikut membantu mensukseskan strategi tersebut.

\subsubsection{Implementasi Strategis}

Strategi yang telah dirumuskan sebelumnya diterapkan terhadap apa yang menjadi objek strategi tersebut. Suis Butcher pernah melakukan strategi promosi menu makanan seperti strategi promosi $30+30$, maksud dari $30+30$ yaitu menawarkan harga paket makan siang seharga Rp. 30.000 di ulang tahun Suis Butcher yang ke 30 tahun. Kemudian mengeluarkan promosi menu makanan di hari kemerdekaan Republik Indonesia. Strategi tersebut diimplementasikan pada waktu-waktu tertentu.

\subsubsection{Evaluasi dan pengendalian}

Evaluasi dan pengendalian terhadap strategi dilaukan setiap sebulan sekali dalam general meeting owner dan para manager baik itu personel manger, purchasing manager, accounting manager dan lain sebagainya. Suis Butcher. Disana dilakukan pengkajian terhadap setiap strategi yang diterapkan. Evaluasi dan pengendalian dilakukan ketika strategi dijalankan dan ketika strategi tersebut berhasil ataupun gagal, dengan cara melihat sebab dan akibat kenapa strategi tersebut berhasil atau gagal. Misalnya dilihat dari absensi karyawan, keuangan, kepuasan konsumen, serta quality control terhadap produk yang ditawarkan dari segi rasa, aroma, kebersihan, dan harga. 


\subsection{Analisis SWOT}

Tabel 2. Eksternal Factors Analisys Summary (EFAS)

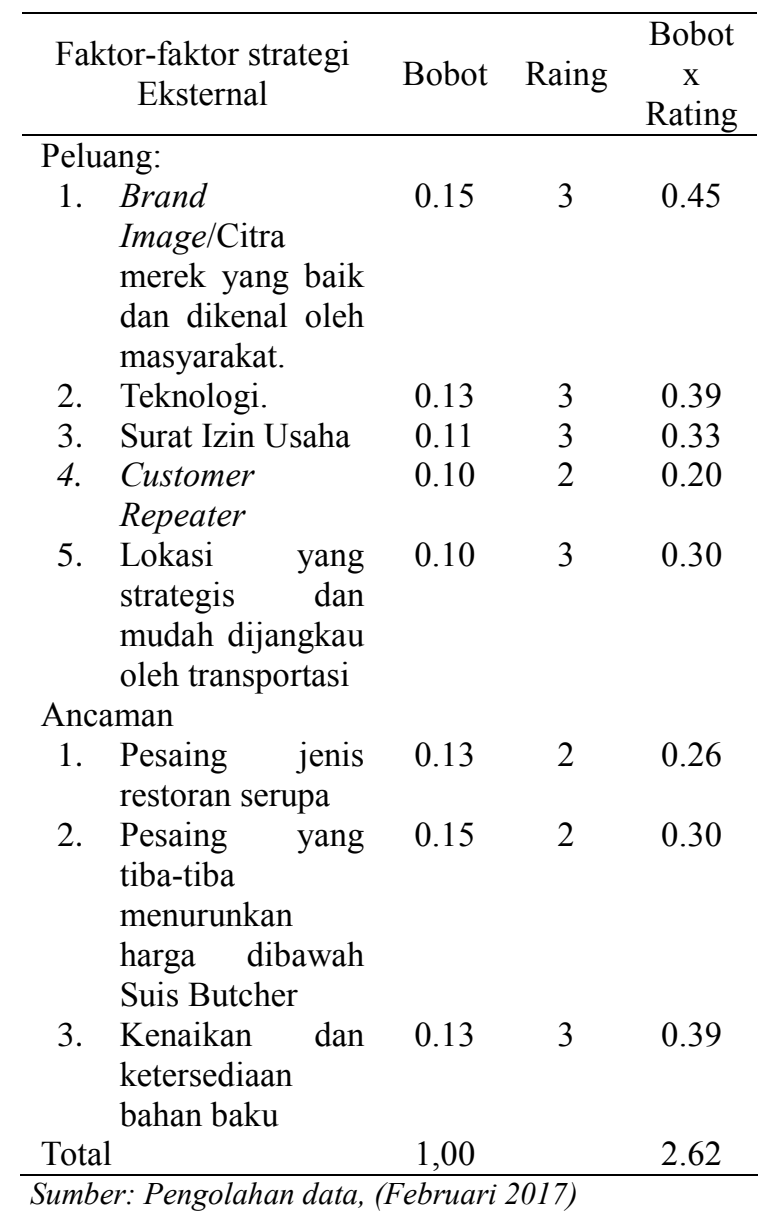

Berdasarkan hasil tabel diatas, maka total skor faktor eksternal adalah sebesar 2.62. Angka ini menunjukan kategori kuat karena berada diatas rata-rata yaitu 2.50. hal ini menunjukan bahwa posisi eksternal strategi peningkatan penjualan Suis Butcher dikatakan kuat sehingga mampu memanfaatkan faktor-faktor peluang yang ada dan menghindari ancaman yang menimbulkan kerugian bagi Suis Butcher.
Tabel 3. Internal Factors Ananlisys Summary (IFAS)

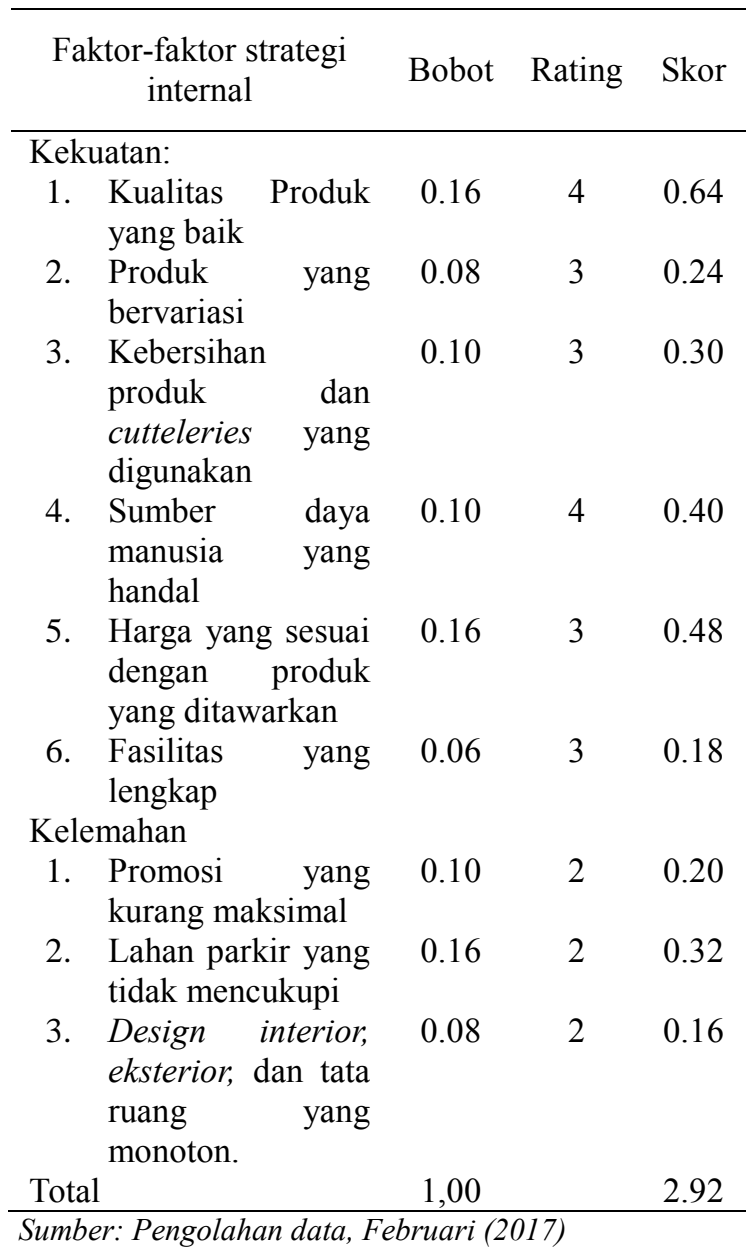

Berdasarkan hasil tersebut, maka total skor faktor internal adalah 2.92. dimana angka ini menunjukan kategori kuat karena berada diatas rata-rata yaitu 2.50 . Hal ini menunjukan bahwa posisi internal strategi peningkatan penjualan di Suis Butcher dikatakan kuat sehingga mampu memanfaatkan faktor-faktor kekuatan yang ada untuk dapat mengatasi faktor-faktor kelemahannya. 


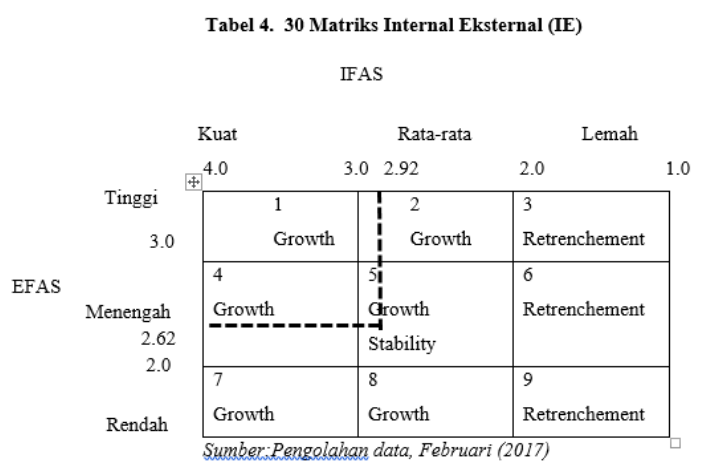

Gambar 1. Matriks Internal Eksternal (IE)

Sel lima (5) yaitu growth strategy yang merupakan pertumbuhan perusahaan itu sendiri. Strategi ini di desain untuk mencapai pertumbuhan, baik dalam penjualan aset, profit maupun kombinasi dari ketiganya Berdasarkan hal tersebut maka strategi yang di terapkan yaitu pertumbuhan strategi melalui integrasi horizontal. Strategi tersebut dapat dicapai dengan cara menurunkan harga, mengembangkan produk baru, menambah kualitas produk atau jasa atau meningkatkan akses ke pasar yang lebih luas. Usaha yang dapat dilakukan yaitu dengan cara meminimalkan biaya sehingga dapat meningkatkan profit.

\subsubsection{Posisi Kuadran SWOT}

Setelah memasukan data kedalam matriks IFAS dan EFAS dan memeberi bobot dan rating untuk masing-masing indikator yang telah ditentukan. Tahapan selanjutnya adalah menghitung kedua skor yang didapat dari kedua matris tersebut. Hal tersebut dilakukan untuk mengetahui posisi perusahaan berada dimana dan untuk mengetahui potensi dari perusahaan yang di teliti. Berikut ini merupakan cara untuk mengetahui posisi kuadran SWOT Suis Butcher:
$\mathrm{X}=$ Total Kekuatan - Total kelemahan

$\mathrm{X}=2.24-0.68=1.56$

$\mathrm{Y}=$ Total Peluang - Total Ancaman

$\mathrm{Y}=1.67-0.95=0.72$

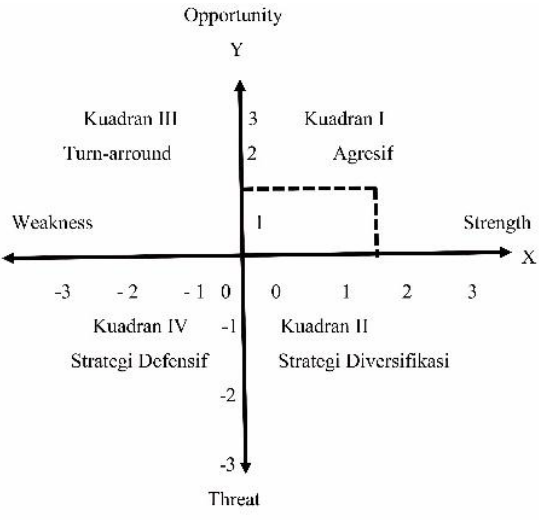

Gambar 2. Diagram Kartesisus

Sumber: Pengolahan data, Februari (2017)

Berdasarkan total peringkat posisi kuadran SWOT untuk Suis Butcher berada di titik (x,y) $(1.57,0.72)$ yang berarti menempati posisi kuadran I. Posisi kuadran I merupakan situasi yang menguntungkan. Perusahaan tersebut mempunyai peluang dan kekuatan sehingga dapat memanfaatkan peluang yang ada. Strategi yang diterapkan dalam kondisi ini adalah mendukung kebijakan pertumbuhan yang agresif.

Berdasarkan hal tersebut maka dapat disimpulkan bahwa Suis Butcher berada dalam posisi yang menguntungkan dimana memiliki kekuatan sehingga dapat memanfaatkan peluang yang ada. Adanya pesaing pada jenis restorang yang serupa menuntut Suis Butcher untuk lebih agresif dalam merebut konsumen, strategi yag dapat dilakukan adalah mengefiesienkan biaya produksi, pengendalian bahan persediaan selain itu juga dapat dilakukan pengembagan produk seperti menbuat variasi menu baru. 
Tabel 4. Matriks SWOT

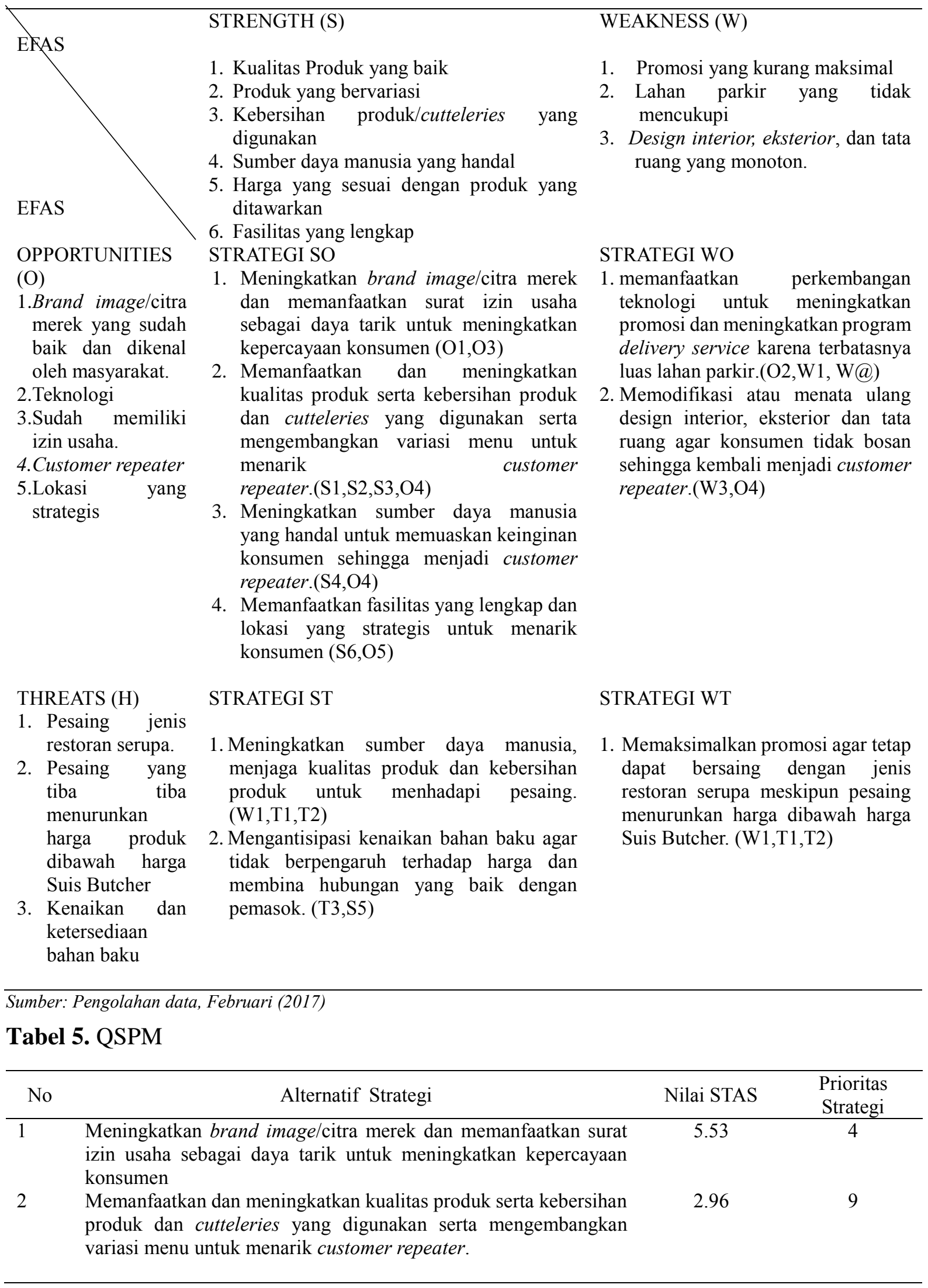




\begin{tabular}{llcc}
\hline No & \multicolumn{1}{c}{ Alternatif Strategi } & Nilai STAS & $\begin{array}{c}\text { Prioritas } \\
\text { Strategi }\end{array}$ \\
\hline 3 & $\begin{array}{l}\text { Meningkatkan sumber daya manusia yang handal untuk } \\
\text { memuaskan keinginan konsumen sehingga menjadi customer } \\
\text { repeater. }\end{array}$ & 5.61 & 3 \\
4 & $\begin{array}{l}\text { Memanfaatkan fasilitas yang lengkap dan lokasi yang strategis } \\
\text { untuk menarik konsumen }\end{array}$ & 5.03 & 1 \\
5 & $\begin{array}{l}\text { Memanfaatkan perkembangan teknologi untuk meningkatkan } \\
\text { promosi. }\end{array}$ & 5.97 & 5 \\
6 & $\begin{array}{l}\text { Memodifikasi atau menata ulang design interior, eksterior dan tata } \\
\text { ruang agar konsumen tidak bosan sehingga kembali menjadi } \\
\text { customer repeater } \\
\text { Meningkatkan sumber daya manusia dan menjaga kualitas produk } \\
\text { dan kebersihan produk untuk menhadapi pesaing }\end{array}$ & 5.51 & 5.16 \\
7 & $\begin{array}{l}\text { Mengantisipasi kenaikan bahan baku agar tidak berpengaruh } \\
\text { terhadap harga dan membina hubungan yang baik dengan pemasok. } \\
\text { Memaksimalkan promosi agar tetap dapat bersaing dengan jenis } \\
\text { restoran serupa meskipun pesaing menurunkan harga dibawah } \\
\text { harga Suis Butcher. }\end{array}$ & 5.33 \\
6
\end{tabular}

\section{Kesimpulan}

Berdasarkan penelitian yang dilakukan di Suis Butcher cabang Setiabudi, maka dapat ditarik kesimpulan dalam upaya meningkatkan strategi penjualan di Suis Butcher cabang Setiabudi yaitu dengan cara a), Memanfaatkan perkembangan teknologi untuk meningkatkan promosi dan meningkatkan delivery service b), Memaksimalkan promosi agar tetap dapat bersaing dengan jenis restoran serupa meskipun pesaing menurunkan harga dibawah harga Suis Butcher c), Meningkatkan sumber daya manusia yang handal untuk memuaskan keinginan konsumen sehingga menjadi customer repeater, d).Meningkatkan brand image/citra merek dan memanfaatkan surat izin usaha sebagai daya tarik untuk meningkatkan kepercayaan konsumen e), Memodifikasi atau menata ulang design interior, eksterior dan tata ruang agar konsumen tidak bosan sehingga kembali menjadi customer repeater, f), Mengantisipasi kenaikan bahan baku agar tidak berpengaruh terhadap harga dan membina hubungan yang baik dengan pemasok, g). Meningkatkan sumber daya manusia dan menjaga kualitas produk dan kebersihan produk untuk menhadapi pesaing, h), Memanfaatkan fasilitas yang lengkap dan lokasi yang strategis untuk menarik konsumen, i)Memanfaatkan dan meningkatkan kualitas produk serta kebersihan produk dan cutteleries yang digunakan serta mengembangkan variasi menu untuk menarik customer repeater.

\section{Daftar Pustaka}

Arista, D. (2016, Januari 28). Tren Terbaru: Masyarakat Indonesia Lebih Suka Makanan Cepat Saji. Retrieved from Tribunners:

http://www.tribunnews.com/tribunner s/2016/01/28/tren-terbarumasyarakat-indonesia-lebih-sukamakanan-cepat-saji. Diakses pada 22 Februari 2017

Disbudpar Bandung. (2015). Laporan Kinerja Instansi Pemerintas Dinas Kebudayaan dan Pariwisata Kota 
Bandung Tahun 2015. Retrieved from portal.bandung.go.id:

https://portal.bandung.go.id/storage/k onten-

lama/download/lkip2016/lkip2015_di sbudpar.pdf. Diakses pada 4 Maret 2017

David, F. R. (2009). Strategic Management. Jakarta: Salemba.

David, F. R. (2010). Manajemen Strategi Konsep. Jakarta: Salemba Empat.

Husein, U. (2008). Metode Riset Bisnis. Jakarta: Indeks Kelompok Media.

Jamiko, R. (2004). Manajemen Strategi. Yogyakarta: BPFE.

Marwan, A. (1991). Marketing.Cetakan Kedua. Yogyakarta: AMPYKPN.

Mawardi, A. F. (2016). Analisis Strategi Pemasaran Perusahaan yang Berorientasi Ekspor dalam Peningkatan Volume penjualan (Studi pada PT Kharisma Rotan Mandiri di Sukoharjo) . Jurnal Administrasi Bisnis, 4.

Nazir, M. (2005). Metode Penelitian (Cetakan Keenam ed.). Bogor: Ghalia Indonesia.

Philip Kotler, K. L. (2009). Manajemen Pemasaran (Vol. Jilid 1). Jakarta: Airlangga.

Pontas, M. (2011). Manajemen Operasi dan Produksi. jakara: andi.

Rangkuti, F. (2009). Strategi Promosi yang Kreatif dan Analisis Kasus. Jakarta: PT Gramedia.

Rangkuti, F. (2009). Strategi Promosi yang Kreatif dan Analisis Kasus. Jakarta: PT Gramedia.

Rangkuti, F. (2016). Analisis SWOT Teknik Membedah Kasus Bisnis. Jakarta: Gramedia Pustaka Utama.

Rangkuti, F. (2016). Analisis Swot Teknik Membedah Kasus Bisnis . Jakarta: PT Gramedia Pustaka Utama.

Riduan. (2005). Belajar Mudah Penelitian Untuk Guru, Karyawan dan Peneliti Pemula. Bandung: Alfabeta.
Rismiati, E. C., \& Suratno, I. B. (2001). Pemasaran Barang dan Jasa. Yogyakarta: Kanius.

S, Adi. (2014, Agustus 08). Pengertian Peningkatan Menurut Para Ahli. Retrieved from duniapelajar.com : http://www.duniapelajar.com/2014/0 8/08/pengertian-peningkatanmenurut-para-ahli/. Diakses pada 4 Maret 2017

S.Pendit, N. (2003). Ilmu Pariwisata. Jakarta: PT Pradya Paramita.

Sevita, S. (2006). Perancangan interior restoran Steak House di Malang. Petra Christian University.

Soekresno. (2000 Edisi ke II). Manajemen Food and Beverage, Service Hotel. Jakarta: PT Gramedia Pustaka Utama.

Suarthana. (2006). Manajemen Perhotelan edisi Kantor Depan. Kuta Utara: Mapindo.

Sugiyono, P. D. (2004). Metode Penelitian Bisnis. Bandung: Alfabeta.

Sulistiyono, A. (2009). Manajemen Penyelenggaraan Hotel. Bandung: Alfabeta.

Tjiptono, F. (2002). Strategi Pemasaran. Yogyakarta: Andi offset.

Umar, H. (2008). Strategic Management in Action. Yogyakarta: PT Gramedia Pustaka Utama.

Wahab, D. S. (1975). Tourism Management London: Tourism Internasional Press.

Warso, S. P. (2016). Pengaruh Kualitas Pelayanan, Desain, dan Harga Terhadap Kepuasan Pelanggan yang Berdampak pada Peningkatan Penjualan di Percetakan Teaching Factory Gradasi Semarang. Journal of Management, 7.

Wheelen, J. D. (2001). Manajemen Strategis. Yogyakarta: ANDI

Widianto, S. (2015, November 23). Bandung Ditetapkan Sebagai Destinasi Wisata Kuliner Indonesia. Retrieved from www.pikiranrakyat.com: http://www.pikiran- 
rakyat.com/wisata/2015/11/23/35097

5/bandung-ditetapkan-sebagai-

destinasi-wisata-kuliner-indonesia.

Diakses pada 4 Maret 2017

Yoeti, O. (1996). Pemasaran Pariwisata.

Bandung: Angkasa . 